\title{
Sanat Dökümantasyonundan Bürokratik Dökümantasyona: Bir "Döngü"
}

\author{
Öğr. Gör. Dr. Harika Esra Oskay - Malicki
}

Makale Geliş Tarihi: 14.10.2016

Yayına Kabul Tarihi: 05.04.2017

\section{Özet}

Sanatta maddesizleşme tartışmaları sonucunda, belgenin sanat nesnesini ikame eden bir araç olarak kullanılmaya başlandığı 1960'lardan farklı olarak teknolojik/bürokratik dokümantasyonunun (Groys) yaşamı biçimlendirdiği günümüzde sanat dökümantasyonu farklı bir anlam kazanır. Yaşamla arasında başka türlü bir ilişki kurmaya çalışan sanat üretiminin başvurduğu araç / aracı olarak "belgelemek" ve "sunmak" arasındaki farkta temellenen günümüz sanatında dökümantasyon belgenin ikincil statüsünde bir kaymaya işaret eder. Bu metin, sanatta belge kullanımının, belgesel retoriğin aldığı bu yeni biçimi Francis Alÿs'in pratiği üzerinden incelemeyi amaçlar. Alÿs'in "Döngü” isimli işini referans noktası olarak alarak sanatta belge kullanımının sanat nesnesi, sanat üretimi, sanat ve yaşam arasındaki ilişkiyi göz önüne alarak irdeler.

Anahtar Kelimeler: Sanat Dökümantasyonu, Belge, Bürokratik Dökümantasyon.

\section{FROM ART DOCUMENTATION TO BUREUCRATIC DOCUMENTATION: A “LOOP”}

\begin{abstract}
While the discussions on dematerialisation of art in 1960s, indicated the use of documentation as a tool for displacing art object, art documentation retains a different meaning today as a consequence of technological/bureaucratic documentation shaping our lives. Today, the act of documentation in art is founded on the difference between "documenting" and "presenting" as a consequence of establishing a different relationship with life. In that sense, this particular use of documentation marks a shift from the secondary status of the document. This article aims to anAlÿse this new form of documentation and documentary rhetoric through the practice of Francis Alÿs. With reference to Alys' work "The Loop", the text explores the use of document in relation to art object, art practice and life.
\end{abstract}

Keywords: Art Documentation, Document, Bureaucratic Documentation.

Öğr. Gör. Dr. H. Esra Oskay-Malicki Gazi Üniversitesi, Güzel Sanatlar Fakültesi, Resim Bölümü, 
Belgesel kipi sanat pratiğinin gündemine sanatın nesnesinin maddesizleşmesi üzerine dönen tartışmaların yoğunlaştığı dönemde bir olanak olarak girer. 60lar ve 70ler, belgenin bir araç olarak sanat üretiminde kullanılmaya başlandığı, belgesel retoriğinin sanat terminolojisine yavaş yavaş yerleştiği bir dönemdir. Zamana meydan okuyan sanat nesnesini geçici varlığıyla sorgulayan performansları paradoksal bir şekilde kendi zamanının ötesinde bir zamana taşıyarak ölümsüzleştirmenin aracıdır dökümantasyon. Şimdi ve burada olmayı, icra edildiği an içinde tükenmeyi merkezine koyan bir üretimin temelindedir. Benzer bir şekilde, nesnenin yerine fikri koyan kavramsal sanatta da bir anti-nesne olarak düşünülür belge. Nesneyi değil düşünsel süreci vurgulayan kavramsal sanat da bir ara nesne olarak belgenin bu ikincil varoluşuna başvurur.

Martha Buskirk (2003), sanatta belge kullanımı ve belgesel dilin sanat alanındaki tezahürünü üç farklı başlık altında inceler: "yapıtın belgesi, yapıtta belgenin kullanılması, ve belgenin sanat yapıtı olarak görülmesi"(s.223). Buskirk'in sınıflandırması, temelde geçici olanın, ele gelmeyenin kaydını tutma aracı olarak kavramsallaştırır belgeyi. Bu üç yaklaşımda da zaman ve mekan matriksi içinde bir taşınma söz konusudur. Ne performansdaki bedenin an içindeki devinimi, ne de düşüncenin maddesi bir nesnede durur çünkü. Bir aracıya, taşınmaya intiyaç duyar bu maddesiz madde. Bu anlamda belge, varlığını kendi dışında bir oluşa borçlu bir bağımlı nesne olarak sanat nesnesini ikame eder, ona vekalet eder.

Orijinali kopyalayan, başka bir zamanda yedekleyen belge "geçici olanı sabitleme ve yeniden tekrar edilebilir kılma dürtüsüne" cevap verir (Doane,2002: 23). Mary Ann Doane'nın "arşivsel dürtü" olarak tanımladığı bu olgu, 19. yüzyılda bir kamera merceğinin aracılığıyla dünyayı kavrayan ve ışığa hassas bir plaka üzerinde bu anlık kavrayışı sabitleyen "kamera önünde olup biten her şeyi kaydeden" teknoloji ile gündeme gelmiştir öncelikle (a.g.y). 70'lerde maddesizleşen sanat üretimini belgelemede kullanılan başat araç olarak fotoğraf da gerçeğe olan sadakatinden nadiren şüphe duyduğumuz bir imge üretimi aracı olarak göndergesiyle "fiziksel" bir ilişki kurar (Kraus, 1977: 198). Her ne kadar fotoğrafın görüntü üretme biçimi analog teknolojiden dijitale geçişte farklı bir fiziksellik ima ediyor olsa da, "şimdi ve burada" olanı taşıyan bir olanak olarak "mevcudiyetin deneyimi"ni verir fotoğrafik belge gene de. Fotoğrafı çekilen nesnenin orada olduğunu, fotoğrafı çekenin şahitliğini kanıtlar.

Günümüz sanatında belge kullanımının artışına dikkat çeken Boris Groys $\mathrm{da}$, kendini şimdi ve burada mevcut eden (present), görünür kılan sanat nesnesinden sanat dokümantasyonuna doğru bir kayma yaşandığını 
belirtir. Sanat dokümantasyonunun sanat nesnesiyle kurduğu ilişkiyi Walter Benjamin'in orjinal ve kopya arasındaki ayrımı çizen, "şimdi ve burada" olmanın halesiolaraktanımlayabileceğimiz aura kavramının perspektifinden okur. Topolojik bir kavram olarak aura belirli bir yere ve zamana ait olan orjinalin mührüdür. Böyle düşünüldüğünde sanat nesnesinin sureti olarak, orijinal ve kopya arasındaki ilişkide temellendirir belgeyi Groys. Ancak aslına birebir bir benzerlikle yaklaşmaya çalışan kopyadan farklı olarak "resim, çizim, fotoğraf, video, metin ve enstalasyon" (Groys, 2008: 68) gibi biçimler alır biyopolitika çağında sanat dökümantasyonu. Yer ve zaman değiştirdiği kadar, biçim de değiştirir.

\section{Sanat Yapıtının Dökümantasyonundan Sanat Dökümantasyonuna}

Boris Groys, günümüzde sanat yapıtındansa sanat dokümantasyonlarılya karşılaşmamızı "şimdi ve burada" varolan, bir an sonra kaybolacak yaşamla girişilen mücadelenin bir sonucu olarak görür. "Anlatılan ve belgelenen ancak gösterilemeyen veya varedilemeyen bir şey olarak" yaşam (Groys, 2008: 66) ancakonun suretleri, belgelerisayesinde kavranabilir. Bizdenuzak, ele geçirilemez olan "o an" ancak suretleriyle şimdiki zamana taşınabilir, "ulaşma imkânımız olmayana" ancak onun kopyaları yaklaştırabilir bizi (Kitamura, 2010: 47). Temsile (representation) gelmeyen, yeniden mevcut edilemeyen, buraya taşınamayan o an, yakalanamayan yaşam belgenin suretleriyle ulaşılabilir olur. Groys'a göre (2008: 54) sanat yapıtından sanat dökümantasyonuna doğru bu kaymanın temelinde yaşama yapılan vurgu, bir sonuca varmayan amaçsız "saf bir aktivite" olarak hayatı göstermesunma arzusu yatar. Bu çerçeve içinde dökümantasyon kendine has bir ifade biçimi olarak yeni bir karakter bulmaya başlar.

Boris Groys'un geliştirdiği şekliyle sanat dökümantasyonu fikri ilk bakışta Buskirk'in üç aşamalı şemasında yapıtı belgeleyen bir aracı olarak belge kullanımını tasvir ediyor gibi görünse de belgeyle yapıtın arasındaki ayrımın belirsizleştiği, sanat üretiminin biçiminde bir kırılmanın baş gösterdiği bir durumu tanımlar daha çok. Örneğin, bir performansın belgesinde yapıtın nerede bitip belgeselin hangi zaman aralığının kaydını tuttuğu net bir şekilde belirlenmişken, Groys'un işaret ettiği yeni üretim biçiminde bu iki an geçişlilik içindedir. Dökümantasyon, bu üretim biçiminde sanatın varolabildiği tek biçimdir, çünkü "en başından beri bu sanatsal aktiviteler sanatın kendini göstereceği bir sanat eseri üretmeye hizmet etmezler" (Groys, 2008: 54). Yapıt belgelerinin dışında var olmaz. Sanat nesnesinin geçici maddesini şimdiye ve sonraya taşıyan, yapıtın kaydını tutan bir araç olarak belgeselin ikincil statüsü değişir. Söz konusu olan belgeleriyle varlığını sürdüren bir yapıt değil, başka türlü var olamayacak "biçimi değişmiş bir 
sanat edimidir" (Groys, 2008: 54).

Belgeyi sanat yapıtından farklı bir mevcudiyet ekonomisi üzerinden düşünen Groys, dökümantasyonun sanatı sunmadığını (present), ancak belgelediğini (document) belirtir. Bu iki eylem arasındaki ayrımda belgenin sanat nesnesiyle kurduğu ilişkideki değişimin dayandığı zemin kurulur. Belirli bir anda mevcut olan, zamana bağımlı sanatsal üretimini sergilemek, belgesi vasıtasıyla orijinal anı hatırlamak için kullanılan dokümantasyondan farklı olarak, geçmişte gerçekleşen bir sanat olayını sergileme iddiasında olmayan farklı bir tür sanat dokümantasyonu söz konusudur günümüzde (Groys, 2008).

Sanat dokümantasyonunda bu yeni dönemin üretim biçimleri "gündelik hayata yapılan müdahaleler, uzun ve kompleks tartışma ve analiz süreçleri, alışılmadık yaşam durumlarının yaratılması, farklı kültür ve çevrelerde sanatın algılanması üzerine yapılan sanatsal incelemeler ..." gibi farklı formatlarda gösterir kendini (Groys, 2008: 54). Böyle bir sanat üretimi geleneksel anlamda "yaratıc bir eylemin" sonucunda üretilen sanat nesnesiyle sonuçlanmaz. Bir nesnede form bulmayı hedeflemeyen, işlevsiz, hayat gibi "saf ve amaçsız bir aktivite" dir bu biçimi tanımlayan. $\mathrm{Bu}$ anlamda geçmişte vuku bulan bir sanat eyleminin şimdiki zamana taşınması, bir "nesne formunda" kendi açması değildir söz konusu olan. Nesneyle belgesinin sınırlarının belirsizleştiği noktada "başka türlü temsil edilemeyecek bir sanatsal aktivitenin mümkün olan tek biçimi" dir sanatsal dökümantasyon (Groys, 2008: 54).

$\mathrm{Bu}$ anlamda belgenin ikincil statüsünden çıkıp sanat üretiminde başat rol oynayan bir şekilde düşünüldüğü günümüz sanatında dökümantasyon, "sanatı belgeler, sunmaz" (Groys, 2008: 54). Ancak orijinalin kopyasında olduğu gibi bir orijini yoktur bu belgenin. Groys'un orijinal ve kopya arasındaki ilişki üzerine kurduğu, "şimdi ve burada"yı başka bir zamana taşıyan belge, artık belgelediği ile farklı bir ilişki içindedir. Kendinden müstakil bir sanat nesnesinin ikamesi değildir.

\section{Francis Alÿs'in Yapıt Ve Belge Arasındaki “Döngü"sü}

Bu anlamda Francis Alÿs'in belge ve yapıt arasındaki ilişkiyi her seferinde yeniden kurmayı amaçlayan pratiği bu ikisi arasındaki ilişkinin yeniden tanımlandığı bir üretim biçimine örnek olarak incelebilir. Sanat pratiğini "eylemler, happeningler, aksiyonlar" (Platt, 2010) üzerine kuran Alÿs'in yapıtları şimdi, şu anda olup bitiveren yaşamın bitimli materyalinden 
biçilmiştir. Alÿs'in üretiminin eyleme olan vurgusu, onun yapıtlarındaki belge kullanımını anı ikame eden "yapıtın belgesi" olarak düşünmeye itebilirse de bizi, belgeleme meselesi burada yapıta içkin bir çözüm gerektirir. Bu anlamda Gerardo Mosquera'nın Alÿs'in pratiğinde iki önemli safha olduğuna dair tespiti önemlidir; Alÿs'in kurguladığı, sahnelediği olaylar ve bu olayların "iletişimi, tercümesi" Alÿs'in üretimini belirler (Mosquera, 2005: 66). Burada söz konusu olan bir performansı takip eden, yapıtı seyircisine belgesi aracılığıyla ileten bir yaklaşım değildir basitçe. Alÿs, yapıt ve belge arasında kurduğu denklem içinde "mevcut durumdan beklenmedik bir uzaklaşma yaratacak durumlar yaratma, seyirciyi bu yaratılmış durumları deneyimlemeye teşvik etme" peşindedir (Ferguson, 2007: 40). Bu anlamda "durum" a yapılan vurgu, onun bitimli ve ele geçmez yaşamın anlık şartlarıyla hareket ettiğini ve yapıtı "saf ve amaçsız yaşamın" içine yerleştirdiğini gösterir. Seyircisini içinde bulunduğu "durum" dan, yeni "durumlar" yaratarak uzaklaştırmayı amaçlayan Alÿs'in önerdiği seyir biçimi, klasik anlamda belge vasıtasıyla orijinal yapıtı, eylemi "hatırlama" ödeviyle hareket etmez. Groys'un tabiriyle "alışılmadık yaşam durumları yaratarak", yaşam içinde başka türlü yaşamsal olanakları yarattığı durumlarla seyircisini geçmişe yönelik değil şimdiki zamana dair bir düşünceye çağııır. Belgenin ima ettiği "hatırlama" eylemi yerine, "hayal etme" (imagine), yani başka türlü olasılıkları düşünen bir imge (image) üretme biçimi önerir.

Alÿs'in 1997 tarihli "Loop/ Döngü" işi, belge ve yapıt arasındaki sınııın yeniden tanımlandığı bu yeni üretim biçimini yeniden düşünmek için bir örnek olarak incelenebilir. Amerika Birleşik Devletleri ve Meksika arasındaki orantısız sınır politikalarını gündeme taşıyan bu işinde Alÿs, Meksika vatandaşlarının sınırda karşılaştıkları zorlukların vücut bulduğu 26 kilometrelik Tijuana - San Diego sınırını reddeden bir rota çizer. Bu reddiyenin somut karşılığını gösteren 26 kilometrelik negatif alandan başlayarak dünya etrafında bir tur atar. Böylece içinde bu adil olmayan sınırı barındırmayan başka türlü bir dünya tanımlar metaforik olarak. 


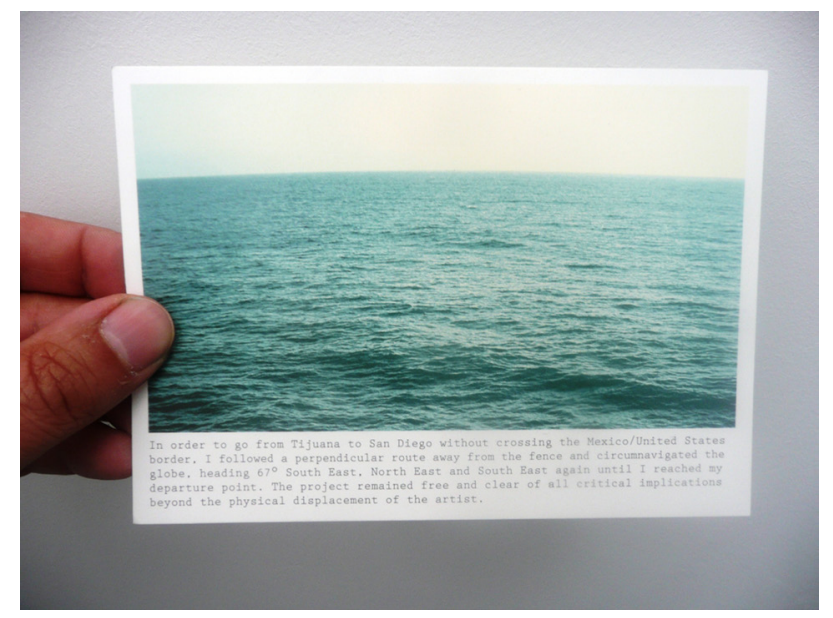

Resim I. Francis Alÿs. Döngü (The Loop). 1997. Kartpostaldan Detay.

Alÿs bu azametli seyahati mütevazı bir kartpostalla belgeler. Kartpostalın ön yüzünde nereye ait olduğu bilinmeyen bir parça deniz manzarası ve bu görüntünün hemen altında Alÿs 'in seyahatini resmi ve olgusal bir dille anlatan aşağıdaki metin yer alır:

\begin{abstract}
Meksika / Amerika Birleşik Devletleri sınırını aşmadan Tijuana'dan San Diego'ya gidebilmek için, bu sınırdan uzak dikey bir rota izleyerek dünyanın çevresinde dolaştım, 67 derece Güney Doğu, Kuzey Doğu ve gene Güney Doğuya giderek, çıkış noktama ulaştım (Alÿs'in Döngü işi için ürettiği kartpostalın ön yüzünde yer alan metnin çevirisi).
\end{abstract}

Francis Alÿs'in başvurduğu belgeleme araçları olarak metnin olgusal dili, kartpostaldaki fotoğrafik görüntü ve seyahati haritalayan görsel, seyircisini belirli bir mesafede tutan nesnel bir belgesel dile yaslanır. Ancak bu nesnellik ifradı kendi sınırlarına dayanır. Fotoğrafik görüntünün ima ettiği geleneksel belgesel retoriğinin nesnelliği, nereye ve hangi zamana ait olduğu bilinmeyen bu deniz parçasında kırılır. Bu anonim, "yersiz yurtsuz", zamansız deniz görüntüsü, anı yakalayan bir belgeleme aracı olarak fotoğrafın işlevini, fotoğrafın belgesel mantığını işlevsiz bırakır. Benzer bir ters yüz etme Alÿs'in seyahat rotasının detaylarının verildiği haritada, kıtaların alışıldık olduğumuz yerleşiminin bozulmasında da görülür. Amerika kıtasını doğuya yerleştiren Alÿs, bu ufak jestle nesnel gerçekliğin tarafsız bilgisine "beklenmedik bir uzaklaşma" yaratır. 


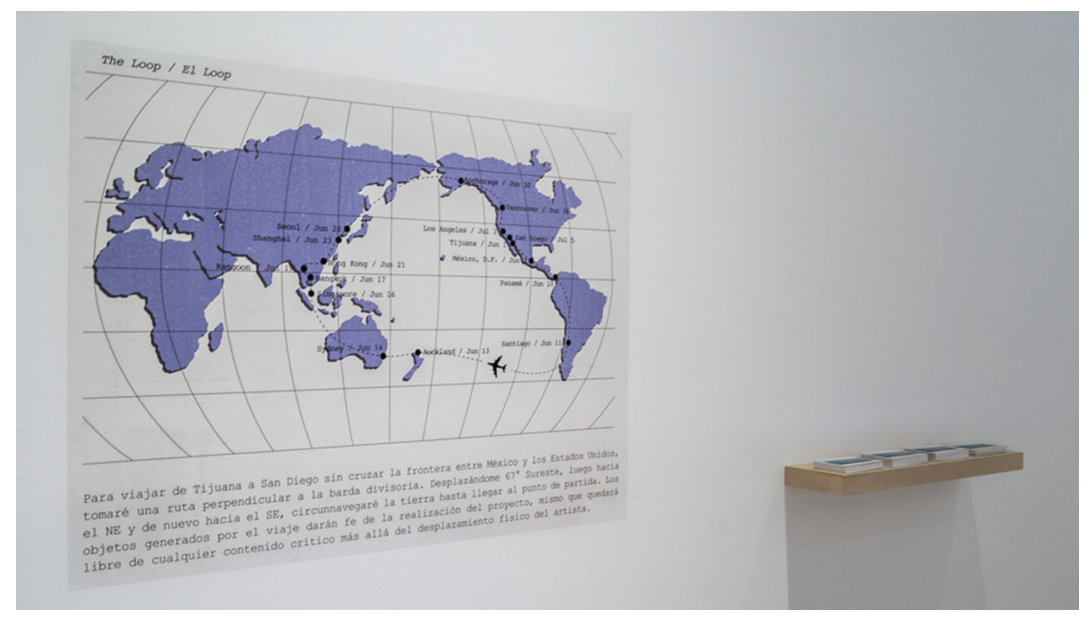

Resim 2. Francis Alÿs. Döngü (The Loop). 1997. Sergiden Görünüm

Böylece belgenin retoriğine her başvurduğunda onun mantığına şerh düşer. Burada Alÿs'in intilaflı olduğu belirli bir belgeleme mantığıdır öte yandan. "Bios"u, yani yaşamı "teknik dökümantasyonlara", bürokratik figürlere tercüme eden mantıktır kaçındığı. Boris Groys'un modern biyoiktidar çağının başat aracı olarak tanımladığı "teknik/bürokratik dökümantasyon" planlar, kanunlar, yönetmeliklerle yaşamı düzenlerken, bu çağın sanatı da dökümantasyon mantığıyla yaşamı belgelemeye çalışmaktadır. Ama bürokrasinin ötesinde bir hayat tasavvur eden bir dökümantasyon peşinde çalışır bu yaklaşım. 26 kilometrelik nicel bir ölçü birimini sınırın iki ayrı tarafında duran yaşamlara ölçüsüzce paylaştıran sınır politikalarında kendini gösteren, yaşamı organize eden, "çizelgeleri canlı varlığa yeğleyen"1 biyoiktidara ve onun teknik diline bir alternatif geliştirme peşindedir günümüzde"sanatsal dökümantasyon".

Sanatsal dökümantasyonu diğer belgeleme biçimlerinden ayıran temel nokta "canlı varlığa" yöneliştir bu anlamda. Bu da anlatıya yapılan vurguyla ulaşılır: "sanatsal dökümantasyon: ister gerçek ister kurgu olsun, temelde anlatısaldır"(Groys, 2008: 57). Yaşama yaşamsallığını veren bu "anlatısal" öğedir Groys'a göre. Bu anlamda kişisel bir anlatıyı ileten bir biçim olarak Alÿs'in kartpostalı kullanması, sınır politikalarında kendini gösteren biyopolitikanın ürettiği bürokratik, teknik bir dokümantasyona alternatif olarak görülebilir. "Yaşam döngüsünün suni bir şekilde biçimlendirildiği şartlarda" , keyfi şekilde çizilen sınırların insafına kalmışinsan hareketlerinde, biyoiktidarın Tijuana ve San Diego sınırında tekrarlayan somut ve katı

\footnotetext{
I "Bir yumuşakçayı laboratuvar koşullarına koyduğumuzda onu mu inceliyoruz yoksa çizelgeleri mi? Davranışın kayıtlarını mı inceliyorsunuz? Teoria canlı varlığa mı yöneliyor yoksa bir zihinsel konstrüksüyona mı", (Baker, 19 şubat 1998).
} 
varlığında bir kartpostalla sesini duyurur yaşam. Belge ile hatıra nesnesi arasında bir yerde duran kartpostal (Mosquera, 2005: 76) kişisel olanla toplumsal olanı, nesnellikle öznelliği, sınırın şiddetine maruz kalan bireysel hikâyelerle bu şiddetin bürokratik belgelerinin dilini yan yana getirir.

Öte yandan, Alÿs'in tersten Amerika seyahatinin bir kullanım klavuzu basitliğinde madde madde anlatılı̆̆ı kartpostalın ön yüzündeki metinde bireysel detaylara dair hiçbir ipucu bulunmaz. Birinci tekil şahıs kipiyle yazılmasına rağmen öznenin sesinin, bedeninin duyulmadığı bu metin "geleneksel belgesel" 2 kurgusuna atfedilen "bildirme" (inform) kipinde yazılmış gibidir. Belgeselin "bildiren" dilinde "bir ve aynı" (Roscoe ve Hight, 2001: 6) olan gerçeklik ve onun kaydı arasındaki ilişki sorunsuz bir şekilde gerçekliği bize sunma iddiasındadır. Ancak tam da bize gerçekliği sunduğu noktada "şimdi, burada" tükenir enformasyonun vaat ettiği. Oysa "gerçeklik, deneyim ve onun ifadeleri arasındaki kapanmayan yarık" (Bruner, 1986: 7) yaşamı böylesi bir doğrudanlıkla yakalayabilecek bir temsil biçimine izin vermez. Bu enformasyona dayalı dil, Groys'un" gerçekliğin şeffaf imgelerini üretme" peşindeki "teknik dökümantasyon"un diline yakındır. Oysa sanatın imgeleri "eleştirel ve yapı sökücü bir niyetle" yaklaşır yaşama (Groys, 2008: 116).

Yapıtlarında ulaşmayı arzuladığı formun "masal ya da şehir efsanesi" (Fisher, 2007:118), "söylenti" (Cooke'den aktaran Platt, 2010) gibi zamanla kökeni kaybolan, yaşamın içine sinen maddesiz bir form olduğunu belirtir Alÿs. Mosquera'nın belirttiği gibi yaratılan durumlar ve bu durumların yarattığı etkiler üzerine pratiğini biçimlendiren Alÿs için önemli olan "aracısız, şimdi, yerel, 'topikal' gerçekliğe" (Mosquera, 2007: 70) gönderme yapan eylemin söylentilerde, efsanelerde dilden dile dolaşarak "metaforlaşmasıdır" (a.g.e). Dile yavaş yavaş sızar metafor gibi zamanla ortak bir ifadeye dönüşürek sosyal yapıyı dokuyan diğer ifadelerin yanına yerleşmeyi arzular. Tersine bir yapı sökümünün peşine düşer bu anlamda. Varolan, kanıksanmış gerçeklerin çözülerek açığa çıkarılmasının ardına düşmektense, kendi ortaya koyduğu eylemin giderek kökenini yitirmesinin, efsaneleşmesinin ve yerleşikleşmesinin yollarını arar. Alÿs şimdiki durum içinde farklı durumlar yaratmanın intimallerini bulur efsaneler, mitler ve söylentilerde.

\footnotetext{
${ }^{2}$ Belgesel nitelik ile objektiflik sıkı sıkıya ilişkili olsa da zihnimizde, hatırlamakta fayda var ki belgesel türü içinde farklı perspektiflerin, öznenin, yönetmenin, belgeseli üretenin başat rol oynadığı belgesel biçimleri de tanımlanmaktadır. Belgesel kuramcısı Bill Nicholls belgesel film türü içinde altı farklı alt tür tanımlar örneğin poetik, açıklayıcı, katılımcı, gözlemci, refleksif ve performatif (2001: 99).
} 


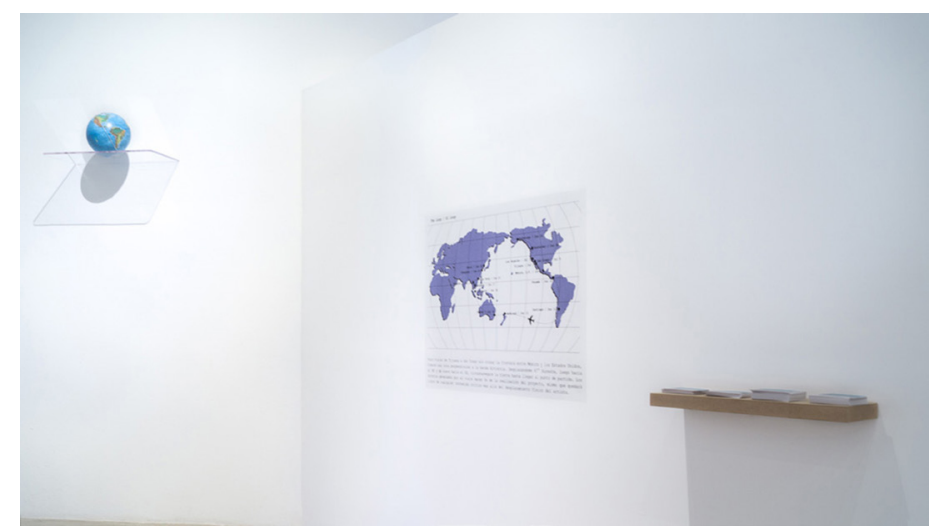

Resim 3. Döngü, "A Story Of Deception/ Bir Aldatmaca Hikayesi” Sergisinden Yerleştirme Görünümü, 2010. Tatemodern. Londra.

\section{Topikal Gerçekliğin Metaforlarla iliş̧kisi}

Alÿs şimdiki durum içinde farklı durumlar yaratmanın intimallerini bulur efsaneler, mitler ve söylentilerde. Enformasyona dayalı "doğrulanabilir, tek başına anlaşılabilen (...) doğrudan iletişim" (Benjamin, 1968: 89) modeli yerine yaşama dair deneyimleri aktaran hikâye anlatıcısının dilini tercih eder. Onun "topikal" gerçekliğin, yani şimdi ve burada olanın, zaman içinde kökenininden uzaklaşarak metaforlaşması sürecine yaptığı vurgu, Walter Benjamin'in atasözleri, vecizeler ve hikâyeler arasında kurduğu ilişkiyi akla getirir (Benjamin, 1968). "Bir vecizenin eski bir hikâyenin vuku bulduğu yerde duran bir harabe olduğu söylenebilir" der Benjamin (1968: 86). Dilden dile, bellekten belleğe dolaşan hikâyenin zamanla aşınmış ve mekânda vücut bulmuş halidir metafor da. Zaman içinde çözülen, rüzgârın, yağmurun, güneşin, duvarlarına isimlerini kazıyan insanların etkisiyle ufalanıp dikildiği yere dağılan bir harabe gibi her yerdedir. Alÿs, yarattığı durumların, bu durumların belgesi niteliğindeki söylenceler ve hikâyelerle metaforlaşarak gündelik hayatın içine böylesi bir nüfuz edişi arzular.

Alÿs'in hikayelere, efsanelere, mitlere yakın dili böyle bir olanak içinde değerlendirilebilir. Yaşama bir "zanaatkar" hassasiyetiyle yaklaşan, "deneyimin ham maddesini... bütüncül, faydalı ve benzersiz şekillerde biçimlendiren" (Benjamin, 1968:108) bir tavrı örnekler Alÿs. Walter Benjamin'in hikâye anlatıcısının insan yaşamıyla ilişkisini tarifinde karşımıza çıkan bu zanaatkâr figürü, Groys'un sanat dokümantasyonunun temel dürtüsü olan yaşamı merkezine alan, yaşamı yakalamaya çalışan sanatçının kaygısını paylaşır. Materyali insan yaşamı olan hikâye anlatıcısı gibi deneyimin ham maddesine biçim verir. 


\section{Sonuç Yerine}

Sanatsal dökümantasyonun ürettiği yeni sanat üretim biçimlerine ilham veren "uzun ve kompleks tartışma ve analizlerle, alışılmadık yaşam koşulları yaratarak, sanatın farklı kültürlerde ve platformlarda algılanmasını inceleyen politik olarak angaje sanat eylemlerinde vs." kendini gösteren, "gündelik hayata müdahil olan" böylesi bir çözülmedir. Bürokratik dökümantasyonun yaşamı şeffaf, objektif bakışıyla düzenleyen tavrının tersine hayata batar, onun içine doğru köklenerek kaybolur. Alÿs'in üretimi bu anlamda sanatçının jestini günümüze taşıyan sanat yapıtının dökümantasyonundan, günümüz sanatında yaşamla farklı bir karşılaşmayı amaçlayan belge kullanımına dökümantasyonun sanat pratiği içindeki anlamının çatallanmaya başladığı noktayı örnekler. Varolanın izini süren bir belgeleme pratiğinin ötesinde hayatın ele gelmeyen, görünmeyen, gösterilmeye direnen yanını bize anlatmaya çalışan bir pratiğin izinde biyopolitika çağında sanat dökümantasyonunun farkı burada temellenir. 


\section{Kaynakça}

Bruner, E. (1986). The Anthropology of Experience. Urbana: University of Illinois Press.

Buskirk, M. (2003). The Contingent Object of Contemporary Art. Cambridge, MA: MIT Press.

Doane, M.A. (2002). The Emergence of Cinematic Time. Modernity, Contingency, The Archive. Cambridge: Harvard University Press.

Ferguson, R. (2007). Interview: Russell Ferguson in Conversation with Francis Alÿs, C. Medina, J. Fisher ve R. Ferguson (Editörler), Francis Alÿs. London: Phaidon Press.

Fisher, J. (2007). Francis Alÿs: In the Spirit of Convivality. C. Medina, J. Fisher, \& R. Ferguson (Editörler). Francis Alÿs. London: Phaidon Press.

Benjamin, W. (1968). The Storyteller. Reflections on the Works of Nikolai Leskov. H. Arendt (ed.). Illuminations. New York: Harcourt, Brace \& World.

Groys, B. (2008). Art Power. Cambridge, MA: MIT Press.

Kitamura, K. (2010). 'Recreating Chaos': Jeremy Deller's The Battle of Orgreave. I. McCalman ve P. A. Pickering (Editörler). Historical Reenactment: From Realism To The Affective Turn. Basingstoke: Palgrave Macmillan.

Krauss, R. (1977). "Notes on the Index: Seventies Art in America”, October, Vol. 3, 68-8I.

Mosquera, G. (2005). Francis Alÿs: When Faith Can Move Mountains. Turner Publishing Company.

Nicholls, B. (200I). Introduction to Documentary. Bloomington, IN: Indiana University Press.

Roscoe, J. ve Hight, C. (200I). Faking It: Mock-Documentary and the Subversion of Factuality. Manchester: Manchester University Press.

\section{Görsel Kaynakları}

Resim I. Francis Alÿs. Döngü (The Loop). 1997. Kartpostaldan detay. http://somelandscapes.blogspot.com.tr/2010/08/sometimes-doing-something-leads-to.html. Erişim tarihi: 12.11 .2016

Resim 2. Francis Alÿs. Döngü (The Loop). 1997. Sergiden Görünüm. http://www.sapslatallera.org/saps/wp-content/uploads/2014/03/alys3.jpg. Erişim tarihi: I2.II.2016 
Resim 3. Döngü, A Story of Deception/ Bir Aldatmaca Hikâyesi sergisinden yerleştirme görünümü, 2010. http://www.saps-latallera.org/saps/wp-content/uploads/2014/03/alys2. jpg. Erişim tarihi: 12.11.2016

\section{İnternet Kaynakları}

Platt, E. (2010). 'Telling stories with a life of their own: Francis Alys'. Tate Etc. issue 19: Summer 2010. Web: http://www.tate.org.uk/context-comment/articles/telling-storieslife-their-own adresinden 16 Eylül 2016'da alınmıştır. 